\title{
Kandungan Flavonoid dan Aktivitas Antibakteri Ekstrak Etanol Daun Sintrong (Crassocephalum crepidiodes) Terhadap Bakteri Bacillus cereus
}

\author{
Flavonoid Content And Antibacterial Activity Of Ethanol Extract Of Sintrong Leaf \\ (Crassocephalum crepidiodes) Against Bacillus cereus
}

\author{
Elia Rose Simanungkalit*, Agus Selamet Duniaji , I Gusti Ayu Ekawati \\ Program Studi Ilmu dan Teknologi Pangan, Fakultas Teknologi Pertanian, \\ Universitas Udayana, Jl. Raya Kampus Unud, Jimbaran, Kuta Selatan, Badung-Bali \\ *Email: erosesimanungkalit@yahoo.com
}

\begin{abstract}
The aim of this research was to determine the content of flavonoid and antibacterial activity of ethanol extract of sintrong leaf (Crassocephalum crepidiodes) on Bacillus cereus. This research used a Completely Randomized Design (CRD) with treatment concentrations extract which were 20\%, 40\%, 60\%, 80\%, and $100 \%$ with three replications and resulting in 15 experimental units. Data were presented with tables and pictures and analyzed in descriptive statistic. Ethanol extract of sintrong leaf contained flavonoid compounds of $1,75 \%$ and was able to inhibit the growth of Bacillus cereus at a concentration of $20 \%$ with an average $12,3 \mathrm{~mm}$ and strong inhibition categories, also has a bacteriostatic character with percentage range death of Bacillus cereus $80,9 \%-93,7 \%$.
\end{abstract}

Keywords: Flavonoid, sintrong leaf, antibacterial, Bacillus cereus

\section{PENDAHULUAN}

Daun sintrong merupakan bagian dari tanaman sintrong (Crassocephalum crepidiodes) yang mengandung senyawa-senyawa metabolit sekunder. Secara tradisional, sintrong juga digunakan sebagai nutraceutikal dan juga dipercaya bisa mengobati berbagai macam penyakit, seperti gangguan pencernaan, sakit kepala, sakit perut, mengobati luka, antelmentik, antiinflamasi, antidiabetes, dan antimalaria (Adjatin et al, 2013). Daun sintrong sering dimanfaatkan sebagai lalapan, urap, pecel dan lain-lain. Di Indonesia, daun sintrong memiliki nama tersendiri di setiap wilayah, seperti di Bali disebut dengan daun kejompot/ kepotpot/ kejengot/ kejelengot, sedangkan di daerah Pulau
Jawa disebut daun sintrong. Daun sintrong (Crassocephalum crepidiodes) memiliki kandungan minyak atsiri (Hidayat dan Napitupulu, 2015), selain itu juga mengandung saponin, flavonoid dan polifenol (Kusdianti, 2008). Hasil penelitian Lestari et al., (2015) ekstrak etanol daun sintrong memiliki kadar total senyawa fenolik sebanyak 1,8581 g GAE/100 g ekstrak.

Hasil ekstrak dari daun sintrong diketahui berpotensi dapat menekan pertumbuhan mikroba. Menurut Elsie, (2010) hasil ekstrak yang mengandung senyawa aktif seperti alkaloid dan flavonoid dapat berpotensi sebagai antibakteri pada Staphylococcus aureus, Bacillus cereus, Escherichia coli, Vibrio cholera dan antijamur 
pada Candida albicans, Aspergillus flavus, dan Aspergillus niger. Hasil penelitian Lestari et al., (2015) menunjukkan bahwa ekstrak etanol daun sintrong pada konsentrasi $10 \%$ dapat menghambat pertumbuhan $S$. aureus dan E. coli dengan diameter zona hambat sebesar 3,16 mm dan 2,77 mm. Selain itu, menurut penelitian Anggraeni, (2017) ekstrak etanol daun sintrong dapat menghambat pertumbuhan Staphylococcus epidermidis dan Pseudomonas aerugenusae dengan Konsentrasi Hambat Minimum (KHM) $5120 \mu \mathrm{g} / \mathrm{mL}$, dan $2560 \mu \mathrm{g} / \mathrm{mL}$.

Bacillus cereus adalah bakteri Gram positif yang menghasilkan enterotoksin. Bakteri ini memproduksi dua jenis toksin, yaitu toksin emetic dan diare. Toksin ini dapat menyebabkan gejala keracunan pangan yang berbeda. B. cereus biasanya terdapat di dalam susu, daging, rempahrempah, dan sereal. Bahan pangan yang mengandung pati merupakan sumber optimal untuk pertumbuhan B.cereus.

Berdasarkan data di atas, maka penelitian ini dilakukan untuk mengetahui kandungan senyawa flavonoid yang dimiliki ekstrak etanol daun sintrong (Crassocephalum crepidiodes) dan aktivitas antibakterinya terhadap Bacillus cereus dengan metode difusi sumur dan metode kontak.

\section{METODE PENELITIAN}

\section{Tempat dan Waktu Penelitian}

Penelitian ini dilakukan di Laboratorium Analisis Pangan, Kampus Sudirman dan UPT Laboratorium Biosains dan Bioteknologi Universitas Udayana, Kampus Bukit Jimbaran.
Pelaksanaan penelitian ini dilakukan pada bulan Juli 2019 sampai dengan September 2019.

\section{Bahan dan alat}

Bahan yang digunakan dalam penelitian ini adalah daun sintrong yang diperoleh dari Desa Kintamani, bakteri Bacillus cereus yang diperoleh dari Laboratorium Mikrobiologi Fakultas Kedokteran, Universitas Udayana, etanol 96\%, aquades, LB (Lactose Broth), NA (Nutrient Agar), alkohol 95\%, $\mathrm{NaNO}_{2}, \quad \mathrm{AlCl}_{3}, \mathrm{NaOH}$, dan methanol.

Alat yang digunakan dalam penelitian ini adalah blender, evaporator, water bath, spektrofotometer $U V$ Vis, autoklaf, batang bengkok, timbangan analitik, mikropipet, freezer, inkubator (Memmert), tip, laminar flow cabinet (Kojair), bunsen, magnetic stirrer, tabung durham, kertas label, vortex, korek api, mikroskop, cawan petri (Pyrex), jarum ose, tabung reaksi (Pyrex), rak tabung reaksi, gelas beker (Pyrex), erlenmeyer (Pyrex), gelas ukur (Pyrex), jangka sorong, tabung effendorf, tissue, plastik HDPE, kertas saring, dan aluminium foil (Klin Park).

\section{Rancangan Penelitian}

Perlakuan pada penelitian yaitu konsentrasi ekstrak daun sintrong, terdiri dari 5 taraf yaitu konsentrasi 20\%, 40\%, 60\%, 80\%, dan $100 \%$. Penelitian ini diulangi sebanyak 3 kali sehingga didapat 15 unit percobaan. Data hasil penelitian disajikan dalam bentuk tabel dan gambar dan dianalisis secara deskriptif. 


\section{Pelaksanaan Penelitian}

Tahap penelitian meliputi beberapa tahapan yaitu persiapan sampel, pembuatan ekstrak, uji kadar flavonoid, uji konfirmasi dan uji aktivitas antibakteri.

\section{Tahap Persiapan Sampel}

Daun sintrong disortasi dan dicuci dengan air mengalir, selanjutnya dipotong menjadi 2 bagian lalu keringkan dengan menggunakan oven pada suhu $50^{\circ} \mathrm{C}$ selama 24 jam hingga mengering. Selanjutnya dilakukan penghancuran menggunakan blender kemudian diayak menggunakan ayakan 60 mesh sehingga didapatkan bubuk yang homogen.

\section{Tahap Pembuatan Ekstrak}

Pembuatan ekstrak daun sintrong dilakukan dengan cara maserasi. Sebanyak 100 gram serbuk daun sintrong dimasukkan ke dalam etanol 96\% sebanyak $1000 \mathrm{~mL}$ (1:10) dan didiamkan selama 3 x 24 jam dalam suhu kamar (Anggraeni, 2017). Ekstrak disaring untuk memisahkan ampas dan filtratnya. Selanjutnya, filtrat dievaporasi pada suhu $40^{\circ} \mathrm{C}$ sampai tidak ada pelarut yang menetes lagi sehingga didapatkan ekstrak kental. Ekstrak etanol daun sintrong dibuat menjadi 5 taraf perlakuan (Gress, 2018 yang dimodifikasi).

\section{Pengujian Kadar Flavonoid Ekstrak Etanol Daun Sintrong}

Pengujian kadar flavonoid dilakukan hanya pada ekstrak etanol daun sintrong konsentrasi $100 \%$ yaitu dianalisis dengan metode kalorimetri menurut Xu and Chang, 2007. Sebanyak 0,01 g sampel dilarutkan dalam $5 \mathrm{~mL}$ metanol, diambil
$200 \mu \mathrm{L}$ lalu direaksikan dengan $2,5 \mathrm{~mL}$ aquades dan $0,15 \mathrm{~mL} \mathrm{NaNO}_{2} 5 \%$ kemudian divorteks dan didiamkan selama 5 menit. Sebanyak $0,3 \mathrm{~mL}$ $\mathrm{AlCl}_{3}$ ditambahkan ke dalam larutan, kemudian didiamkan kembali selama 5 menit. Larutan direaksikan dengan $1 \mathrm{~mL} \mathrm{NaOH}$ kemudian diencerkan dengan aquades hingga volume $5 \mathrm{~mL}$ lalu divorteks dan disentrifuse selama 5 menit, didiamkan selama 30 menit. Diukur absorbansi larutan pada panjang gelombang $510 \mathrm{~nm}$ dengan spektrofotometer UV-Vis (Desmiaty et al., 2009).

\section{Uji Konfirmasi}

Isolat Bacillus cereus yang sudah disegarkan kemudian dibiakkan pada media MYP dengan cara digoreskan agar diperoleh koloni tunggal dan diinkubasi selama 24 jam dengan suhu $37^{\circ} \mathrm{C}$. Diambil satu koloni tunggal, kemudian dimasukkan kedalam LB dan diinkubasi selama 24 jam pada suhu $37^{\circ} \mathrm{C}$. Setelah diinkubasi, dilakukan pewarnaan gram dan diamati bentuk sel melalui mikroskop dengan pembesaran 200x.

\section{Pembuatan Stok Kultur Bacillus cereus}

Diambil satu koloni Bacillus cereus dengan menggunakan jarum ose, lalu ditanamkan pada media Nutrien Agar miring dengan cara menggores, setelah itu diinkubasi dalam inkubator pada suhu $37^{\circ} \mathrm{C}$ selama 24 jam.

\section{Pengujian Aktivitas Antibakteri Dengan Metode Difusi Sumur}

Sebanyak $100 \mu \mathrm{L}$ B. cereus disebar dalam media NA yang telah dipersiapkan. Media didiamkan \pm 15 menit kemudian dilubangi dengan 
tabung durham lalu diisi $\pm 20 \mu \mathrm{L}$ ekstrak etanol daun sintrong sesuai dengan perlakuan. Selanjutnya, diinkubasi pada suhu $37^{\circ} \mathrm{C}$ lalu zona penghambatan diukur dengan jangka sorong sebanyak empat kali di tempat yang berbeda dan hasilnya dirata-ratakan kemudian dikurangi dengan diameter sumur ( $\mathrm{mm})$.

\section{Pengujian Aktivitas Antibakteri Dengan Metode Kontak}

Dipipet 0,2 mL kultur B. cereus ke dalam tabung efendorff dan ditambahkan 0,2 mL ekstrak etanol daun sintrong sesuai perlakuan, lalu diinkubasi pada suhu $37^{\circ} \mathrm{C}$ selama 24 jam. Setelah waktu kontak tercapai, campuran diencerkan hingga $10^{-3}$ kemudian sebanyak $0,1 \mathrm{~mL}$ dari pengenceran $10^{-1}-10^{-3}$ ditanam pada media NA dengan metode sebar kemudian diinkubasi selama 24 jam (Tanzilla et al., 2016 yang sudah dimodifikasi). Pengujian dilakukan dengan menghitung total mikroba yang tumbuh.

\section{HASIL DAN PEMBAHASAN}

\section{Uji Kadar Flavonoid Ekstrak Etanol Daun}

\section{Sintrong}

Pengujian kadar flavonoid ekstrak etanol daun sintrong dilakukan secara kuantitatif. Senyawa flavonoid adalah senyawa aktif yang umumnya digunakan sebagai antibakteri, kadar flavonoid juga digunakan untuk mengetahui besar kecilnya diameter penghambatan pertumbuhan bakteri. Hasil rata-rata kadar flavonoid total ekstrak etanol daun sintrong yaitu sebesar 1,75\% (mg/100g). Kadar ini lebih kecil jika dibandingkan dengan kadar flavonoid ekstrak etanol daun kelor sebesar 7,19\% yang memiliki diameter penghambatan 7,5 $\mathrm{mm}-9,9 \mathrm{~mm}$ (Kenconojati dan Rukmana, 2019). Penelitian Parubak., (2013) juga membuktikan bahwa kadar flavonoid yang diperoleh pada ekstrak daun Akway (Drimys beccariana Gibbs) sebesar 0,36\% dan memiliki diameter penghambatan sebesar 6,9 $\mathrm{mm}-7,3 \mathrm{~mm}$.

Pelarut yang digunakan pada penelitian ini adalah etanol 96\%. Etanol merupakan salah satu pelarut yang bersifat polar. Menurut Moein and Mahmood, (2010) pelarut yang bersifat polar mampu melarutkan fenol lebih baik, dimana turunan fenol tertinggi adalah flavonoid. Flavonoid bekerja sebagai antibakteri dengan cara merusak membran sitoplasma bakteri. Membran sitoplasma bakteri berfungsi sebagai pengatur masuknya nutrisi atau bahan-bahan makanan untuk bakteri. Jika membrane sitoplasma rusak, metabolit penting dalam bakteri akan keluar dan nutrisi untuk menghasilkan energi tidak dapat masuk sehingga terjadi ketidakmampuan sel bakteri untuk tumbuh (Dzen, 2003).

\section{Uji Konfirmasi Bacillus cereus}

Hasil uji konfirmasi menunjukkan bahwa $B$. cereus memiliki bentuk koloni bulat, warna koloni pink keunguan, memiliki bentuk sel basil panjang dan termasuk bakteri Gram positif. Hasil pengamatan terhadap $B$. cereus sesuai dengan pernyataan Fatmasari (2015) yang menyatakan bahwa $B$. cereus memiliki bentuk koloni bulat terbentuk zona, dan berwarna pink keunguan. Pengamatan terhadap warna koloni B. cereus pada media MYP dapat dilihat pada Gambar 1. 


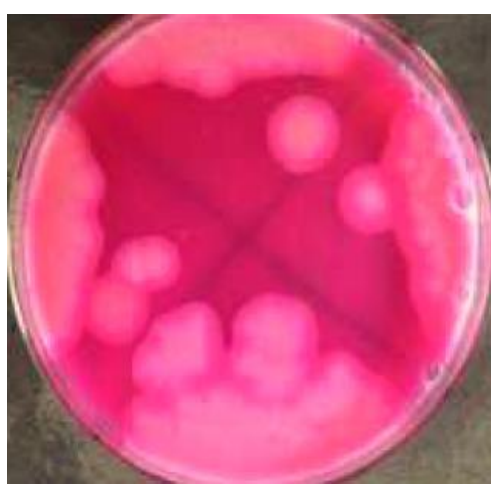

Gambar 1. Bentuk dan warna koloni B. cereus pada MYP Agar

Hasil pengamatan secara mikroskopik menunjukkan bahwa $B$. cereus merupakan bakteri Gram positif. Bakteri Gram positif mempertahankan zat pewarna kristal violet sehingga sel berwarna ungu, sedangkan bakteri Gram negatif akan kehilangan kristal violet ketika diteteskan dengan alcohol. Hal ini disebabkan karena perbedaan ketebalan lapisan peptidoglikan antara bakteri gram positif dan negatif. Hasil pengamatan bakteri dengan mikroskop pada pembesaran 200x dapat dilihat pada Gambar 2 .

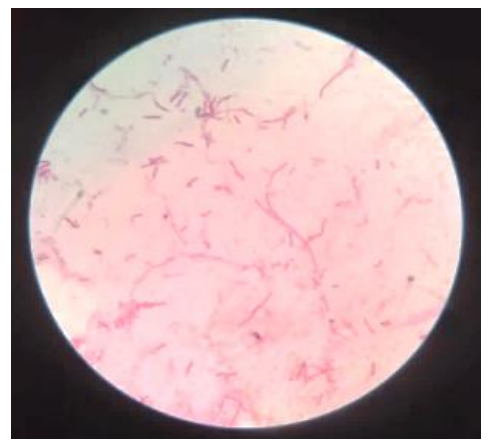

Gambar 2. Bentuk morfologi Bacillus cereus pada pembesaran 200x

Aktivitas Antibakteri Ekstrak Etanol Daun Sintrong (Crassocephalum crepidiode Terhadap Pertumbuhan Bacillus cereus dengan Metode Difusi Sumur
Kategori daya hambat pada diameter penghambatan dibagi menjadi empat kategori, yaitu $<5 \mathrm{~mm}$ lemah, 5-10 $\mathrm{mm}$ sedang, 10-20 mm kuat, dan >20 mm sangat kuat (Davis and Stout, 1971). Berdasarkan Tabel 1 dapat diketahui ratarata penghambatan ekstrak etanol daun sintrong terhadap pertumbuhan B. cereus, dimana ekstrak etanol daun sintrong sudah mampu menghambat pertumbuhan B. cereus dengan kategori kuat dari konsentrasi terendah hingga tertinggi dengan ratarata diameter penghambatan $12,3 \mathrm{~mm}-14,5 \mathrm{~mm}$.

Diameter zona hambat cenderung meningkat seiring meningkatnya konsentrasi ekstrak. Diameter penghambatan B. cereus terendah berada pada konsentrasi $20 \%$ sebesar 12,3 mm, sedangkan diameter penghambatan tertinggi diperoleh pada konsentrasi $100 \%$ sebesar 14,5 mm. Semakin meningkat konsentrasi ekstrak etanol daun sintrong, diameter zona hambat juga semakin besar, dikarenakan semakin tinggi konsentrasi ekstrak etanol daun sintrong dan jumlah zat antibakteri yang terlarut juga semakin banyak sehingga daya hambat terhadap bakteri akan semakin tinggi. Lestari et al., (2015) membuktikan bahwa semakin besar konsentrasi ekstrak etanol daun sintrong yang diberikan, semakin besar pula zona hambat yang terbentuk. Terbentuknya zona hambat menunjukkan bahwa ekstrak etanol daun sintrong memiliki senyawa bioaktif yang berperan sebagai senyawa antibakteri sehingga mampu menghambat pertumbuhan B. cereus. Zona hambat ekstrak etanol daun sintrong terhadap $B$. cereus dapat dilihat pada Gambar 3. 
Tabel 1. Penghambatan ekstrak etanol daun sintrong terhadap B. cereus

\begin{tabular}{cc}
\hline Konsentrasi & Rata-Rata Penghambatan $(\mathrm{mm})$ \\
\hline $20 \%$ & 12,3 \\
$40 \%$ & 12,7 \\
$60 \%$ & 13,2 \\
$80 \%$ & 13,8 \\
$100 \%$ & 14,5 \\
\hline
\end{tabular}

Berdasarkan Gambar 3, zona hambat terbentuk pada konsentrasi terendah 20\% hingga konsentrasi tertinggi 100\%. Konsentrasi ekstrak yang digunakan merupakan faktor yang mempengaruhi besar kecilnya zona hambat yang terbentuk disekitar lubang yang telah diisi ekstrak. Semakin lebar diameter zona hambat yang terbentuk membuktikan kuatnya senyawa bioaktif pada daun dalam menghambat pertumbuhan bakteri. Adanya kandungan flavonoid pada ekstrak etanol daun sintrong, yaitu sebesar $1,75 \%$ (mg/100g) mempengaruhi adanya aktivitas antibakteri. Ekstrak etanol daun sintrong juga memiliki kandungan fenol total sebesar $1,8581 \mathrm{~g}$ GAE/100g (Lestari et al., 2015). Senyawasenyawa tersebut diketahui mampu berperan sebagai antibakteri baik pada bakteri Gram negatif ataupun bakteri Gram positif.

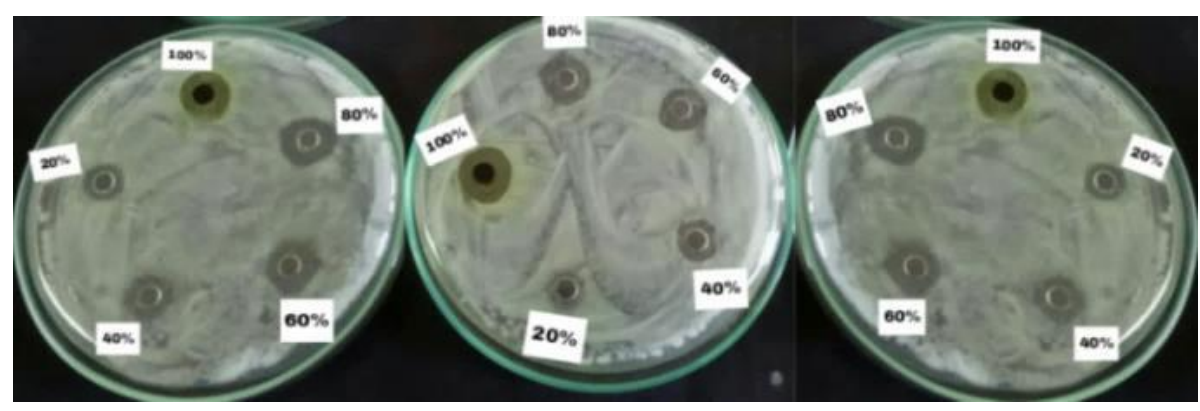

Gambar 3. Zona hambat ekstrak etanol daun sintrong terhadap Bacillus cereus

\section{Aktivitas Antibakteri Ekstrak Etanol Daun \\ Sintrong (Crassocephalum crepidiodes) \\ Terhadap Pertumbuhan Bacillus cereus dengan Metode Kontak}

Total B. cereus yang digunakan pada penelitian ini adalah $1,47 \times 10^{6} \mathrm{CFU} / \mathrm{mL}$ dan setelah dikontakkan pada konsentrasi sesuai perlakuan, B. cereus yang tumbuh mengalami penurunan. Tabel 2 menunjukkan bahwa pada kontak dengan konsentrasi ekstrak 100\%, jumlah B. cereus turun sebanyak $1,4 \times 10^{6}$ dengan kematian bakteri uji sebesar 93,7\%. Pada kontak dengan konsentrasi $80 \%$ jumlah B. cereus turun sebanyak $1,4 \times 10^{6}$ dengan kematian bakteri uji sebesar 92,4\%. Pada kontak dengan konsentrasi $60 \%$ jumlah B. cereus turun sebanyak $1,3 \times 10^{6}$ dengan kematian bakteri uji sebesar 90,5\%. Pada kontak dengan konsentrasi $40 \%$ jumlah B. cereus 
turun sebanyak $1,3 \times 10^{6}$ dengan kematian bakteri uji sebesar $87,8 \%$ dan pada kontak dengan konsentrasi $20 \%$ jumlah $B$. cereus turun sebanyak $1,2 \times 10^{6}$ dengan kematian bakteri uji sebesar $80,9 \%$.

Hal ini membuktikan bahwa semakin tinggi konsentrasi ekstrak etanol daun sintrong yang ditambahkan, semakin tinggi pula kemampuan penghambatannya terhadap pertumbuhan $B$. cereus. Peningkatan konsentrasi ekstrak etanol daun sintrong akan diikuti oleh peningkatan konsentrasi zat bioaktif, sehingga aktivitas antibakteri juga akan semakin tinggi. Hal ini ditandai dengan berkurangnya jumlah koloni bakteri uji ketika konsentrasi ekstrak dinaikkan.

Menurut Baron et al., (1992) jika kematian bakteri uji minimal 99,99\%, maka pada konsentrasi tersebut antibakteri dikatakan bersifat bakterisidal (membunuh bakteri). Sebaliknya, jika kematian kurang dari 99,99\%, maka antibakteri dikatakan bersifat bakteristatik (menghambat pertumbuhan bakteri). Berdasarkan persentase kematian, ekstrak etanol daun sintrong memiliki daya penghambatan kurang dari 99,99\% yang berarti bersifat bakteristatik.

Tabel 2. Penghambatan Ekstrak Etanol Daun Sintrong Terhadap Bacillus cereus Dengan Metode Kontak

\begin{tabular}{cccc}
\hline $\begin{array}{c}\text { Konsentrasi } \\
\text { Ekstrak }\end{array}$ & $\begin{array}{c}\text { Jumlah B.cereus setelah } \\
\text { kontak }(\text { CFU/mL) }\end{array}$ & $\begin{array}{c}\text { Penurunan jumlah } \\
\text { B.cereus } \\
(\text { CFU/mL) }\end{array}$ & $\begin{array}{c}\text { Kematian B.cereus } \\
(\%)\end{array}$ \\
\hline $20 \%$ & $2,6 \times 10^{5}$ & $1,2 \times 10^{6}$ & 80.9 \\
$40 \%$ & $1,7 \times 10^{5}$ & $1,3 \times 10^{6}$ & 87.8 \\
$60 \%$ & $1,3 \times 10^{5}$ & $1,3 \times 10^{6}$ & 90.5 \\
$80 \%$ & $1,1 \times 10^{5}$ & $1,4 \times 10^{6}$ & 92.4 \\
$100 \%$ & $0,9 \times 10^{5}$ & $1,4 \times 10^{6}$ & 93.7 \\
\hline
\end{tabular}

\section{KESIMPULAN DAN SARAN}

\section{Kesimpulan}

1. Ekstrak etanol daun sintrong (Crassocephalum crepidiodes) mengandung total flavonoid sebesar $1,75 \%$

2. Ekstrak etanol daun sintrong (Crassocephalum crepidiodes) mampu mengambat pertumbuhan B.cereus mulai dari konsentrasi $20 \%$ dengan kategori kuat dan membentuk efek bakteristatis dengan persentasi kematian sebesar $80,9 \%-93,7 \%$

\section{Saran}

Perlu dilakukan uji kuantitatif senyawa fitokimia lain pada ekstrak daun sintrong (Crassocephalum crepidiodes) dan uji aktivitas antibakteri ekstrak daun sintrong terhadap bakteri lain.

\section{DAFTAR PUSTAKA}

Adjatin, A., Dansi, A., Badoussi, E., Loko, Y.L., Dansi, M., Gbaguidi, F., Azokpota, P., Ahissou, H., Akoègninou, A., Akpagana, K., and Sanni A. (2013). Phytochemical screening and toxicity studies of Crassocephalum rubens (Juss. ex Jacq.) S. Moore and Crassocephalum crepidioides (Benth.) S. Moore consumed as vegetable in Benin. Journal of Chemical and 
Pharmaceutical Research, 2013, 5(6):160167

Anggraeni, N. 2017. Uji Aktivitas Antibakteri Pada Tumbuhan Tespong (Oenanthe Javanica Dc), Sintrong (Crassocephalum Crepidioides), Dan Pohpohan (Pi Lea Trinerviaw) Terhadap Bakteri Staphylococcus Epidermidis \& Pseudomonas Aerugenosae. [Skripsi]. Sekolah Tinggi Farmasi Bandung Program Studi Strata I Farmasi. Bandung

Baron, E.J., L.R Peterson, dan S.M. Finegold. 1992. Diagnostic Microbiology. $9^{\text {th }}$ Ed. Baile\&Scott's. St. Louis

Desmiaty,Y., J. Ratnawati., dan P. Andini. 2009. Penentuan Jumlah Flavonoid Total Ekstrak Etanol Daun Buah Merah (Pandanus Conoideus Lamk) Secara Kalorimeter Komplementer. Fakultas Farmasi. Universitas Jendral Ahmad Yani. Cimahi. Jawa Barat.

Djajadisastra, A.N. 2007. Penapisan Komponen Antibakteri dan Uji Toksisitas dari Spons Perairan Taka Bonerate Sulawesi Selatan. Skripsi. Bogor. Program Studi Teknologi Hasil Perikanan Fakultas Perikanan dan Ilmu Kelautan Universitas Institut Pertanian Bogor

Fatmasari, 2015. Uji Sensitivitas Antibiotik Kloramfenikol, Siprofloksasin, Eritromisin dan Klindamisin Terhadap Bacillus cereus Yang Diisolasi Dari Daging Sapi di Pasar Tradisional dan Pasar Modern Kota Makassar. Skripsi. Fakultas Kedokteran, Universitas Hasanudin, Makassar

Gress, R.N. 2018. Kandungan Flavonoid dan Antosianin Ekstrak Kayu Secang (Caesalpinia sappan L.) Serta Aktivitas Antibakteri Terhadap Vibrio cholera. Skripsi. Fakultas Teknologi Pertanian. Universitas Udayana

Gunawan. 2002. Ilmu Obat Alam (Farmakologi). Penebar Swadaya. Jakarta: 99-100.
Kenconojati, H dan Nina, R.R. 2019. Daya hambat ekstrak daun Kelor (Moringa oleifera) terhadap Aeromonas hydrophila: studi awal untuk pengobatan aeromoniasis. Universitas Airlangga. Journal of Aquaculture Science April 2019 vol 4 (1): $12-20$

Kusdianti., Nilawati, T. S., Sheba, L. (2008). Tumbuhan Obat di Legok Jero Situ Lembang. Makalah seminar penggalang taksonomi tumbuhan. Bandung: Universitas Pendidikan Indonesia.

Lestari, T., Nurmala., dan Nurmalasari. 2015. Penetapan Kadar Polifenol dan Aktivitas Antibakteri Ekstrak Etanol Daun Sintrong (Crassocephalum crepidiodes (Benth.) $S$. moore). Jurnal Kesehatan Bakti Tunas Husada. Volume 13 Nomor 1 Februari 2015

Moein S., and Mahmood RM. 2010. Relationship between antioxidant properties and phenolics in Zhumeria majdae. Journal of Medicinal Plants Research (7): 517-521

Parubak, A.S. 2013. Senyawa Flavonoid Yang Bersifat Antibakteri Dari Akway (Drimys becariana.Gibbs). Chem. Prog. Vol. 6, No.1

Purwanti, M., Sudarwanto, M., Rahayu, W. P. \& Sanjaya, A. W. 2008. Pertumbuhan Bacillus cereus dan Clostridium perfringens pada Makanan Tambahan Pemulihan yang Dikonsumsi Balita Penderita Gizi Buruk. Jurnal Forum Pascasarjana. Vol. 31 No. 4

Tanzilla, A. 2017. Kemampuan Daya Hambat Ekstrak Daun Pegagan (Centella Asiatica (L.) Urban) Terhadap Pertumbuhan Escherichia coli ATCC 8739. Skripsi. Fakultas Teknologi Pertanian. Universitas Udayana.

Xu, B.J. dan Chang, S.K.C. 2007. A comparative study on phenolic profiles and antioxidant activities of legumes affected by extraction solvent. Journal of Food Science 72: 59-66. 